\title{
SWEA-Dataveg - vegetation of small wetlands in East Africa
}

\author{
Miguel Alvarez, Bodo Maria Möseler, Matthias Josko, Mathias Becker, Matthias \\ Langensiepen, Gunter Menz, Beate Böhme, Helida Oyieke, Collins Handa, Hellen \\ Kamiri, Salome Misana, Emiliana Mwita, Mogha Neema \& Nomé Sakané
}

\begin{abstract}
SWEA (agricultural use and vulnerability of small wetlands in East Africa) is a multidisciplinary project which task is to evaluate the effects of land use on the ecological and socio-economical functions of small wetlands in Kenya and Tanzania. In order to allow the availability of the collected data for further studies we stored them into SWEA-Dataveg (GIVD ID AF-00-006), a database stored in Microsoft Access (mdb-format). Because this project is dealing not only with vegetation science but also with geography, soil science, hydrology and socio-economy, the database also contains information related to these research fields. Additionally, some functional traits of the plant species occurring in the relevés are included in the species list. The sampling areas are concentrated in four localities, two of them in Kenya (Karatina and Rumuruti) and two in Tanzania (Malinda and Lukozi). The vegetation ecology group is dealing in the project with the classification of the vegetation according to species composition, the correlation of plant communities with environmental factors and land uses, and the survey of potential indicator species for the determination of the resilience of wetlands. Once finished the storage, we are considering an adaptation of SWEA-Dataveg into a TURBOVEG-format as well as its extension to further projects (e.g. SWEA phase II) and relevés collected from publications.
\end{abstract}

Keywords: Aquatic plant; bio-indicator; land use; resilience; wetland ecology.

\section{SWEA-Dataveg}

Scope: Relevés in small wetlands of Kenya and Tanzania collected during the sampling activities of the SWEA-project, including semi-natural vegetation (non-used or light used fields), fallows, grasslands and weed communities in crops.

Status: completed and continuing

Period: 2009-2012

Database manager(s): Miguel Alvarez (malvarez@uni-bonn.de); Mathias Becker (mathias.becker@uni-bonn.de)

Owner: SWEA-project

Web address: http://www.wetlands.uni-bonn.de

Availability: according to a specific agreement

Online upload: no

Online search: no

Database format(s): MS Access

Export format(s): MS Access

Publication: [NA]

Plot type(s): normal plots

Plot-size range: $4-10 \mathrm{~m}^{2}$

Non-overlapping plots: 206

Total plot observations: 206

Estimate of existing plots: 1,000

Number of sources: $[N A]$

\section{Completeness: $21 \%$}

Valid taxa: 406

Countries: KE: $50.0 \%$; TZ: $50.0 \%$

Forest: [NA] — Non-forest: [NA]

Guilds: all vascular plants: $100 \%$

Environmental data: [NA]

Performance measure(s): presence/absence only: $2 \%$; cover: $98 \%$

Geographic localisation: small grid (not coarser than $10 \mathrm{~km}$ ): $100 \%$

Sampling periods: $2000-2009: 98.0 \%$; 2010-2019: $2.0 \%$

Information as of 2012-07-12; further details and future updates available from http://www.givd.info/ID/AF-00-006

Miguel Alvarez* (malvarez@uni-bonn.de), Matthias Josko (josko@uni-bonn.de) \& Bodo Maria Möseler (moeseler@uni-bonn.de) Vegetation Ecology, INRES, University of Bonn, Nussallee 9, 53115 Bonn, GERMANY

Mathias Becker (mathias.becker@uni-bonn.de)

Plant Nutrition, INRES, University of Bonn, Karlrobert-Kreiten-Str. 13, 53115 Bonn, GERMANY

Matthias Langensiepen (mlang@uni-bonn.de)

Crop Science, INRES, University of Bonn, Katzenburgweg 5, 53115 Bonn, GERMANY

Gunter Menz (g.menz@uni-bonn.de)

Remote Sensing, Institute of Geography, University of Bonn, Meckenheimer Allee 166, 53115 Bonn, GERMANY 
Beate Böhme (beate.boehme@tbt.tu-freiberg.de)

Soil and Water Conservation Unit, TU Bergakademie Freiberg, Agricolastr. 22, 09599 Freiberg, GERMANY

Helida Oyieke (cbd@ museums.or.ke)

National Museums of Kenya, Nairobi, KENYA

Collins Handa (handacollins@ gmail.com)

National Museums of Kenya, KENYA

Hellen Kamiri (wangechikamiri@yahoo.com)

Karatina University College, Karatina, KENYA

Salome Misana (smisana@ud.co.tz), Emiliana Mwita (emwita@uni-bonn.de)

Department of Geography, DUCE, University of Dar es Salaam, Dar es Salaam, TANZANIA

Mogha Neema (moghang@yahoo.com)

Department of Ecology, DUCE, University of Dar es Salaam, Dar es Salaam, TANZANIA

Nomé Sakané (nsakana@gmail.com)

Plant Production Systems, Wageningen University, Wageningen, NETHERLANDS

*Corresponding author 